OOPEN ACCESS

Engineering Science \& Technology Journal

Volume 2, Issue 1, P. 35-47, March, 2020

Fair East Publishers

Journal Homepage: www.fepbl.com/index.php/estj

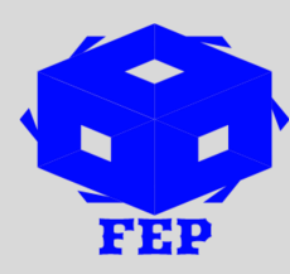

\title{
ANALYSIS OF USE OF VARIOUS MATERIALS IN WATER PURIFICATION PROJECT \\ Bargueno $^{1}$ \\ ${ }^{1}$ Faculty of Engineering and Information Technology, José Eduardo dos Santos Campus, University of Namibia, OngwedivaNamibia
}

*Corresponding Author: Bargueno

Article Received: 05-12-19
Accepted: 04-02-20
Published: 27-03-20

Licensing Details: Author retains the right of this article. The article is distributed under the terms of the $\begin{array}{lllll}\text { Creative } & \text { Commons } & \text { Attribution-NonCommercial } & 4.0 & \text { License }\end{array}$ (http://www.creativecommons.org/licences/by-nc/4.0/) which permits non-commercial use, reproduction and distribution of the work without further permission provided the original work is attributed as specified on the Journal open access page

\section{ABSTRACT}

Availability of clean drinking water is becoming a major issue in the 21 st century. The issue is increased because of decreasing water sources and increased population and related agriculture and industrial consumption requirement. There are different methods of cleaning the water but the world is changing to more environmentally friendly methods. Use of solar still is one of the methods which has lower carbon footprints. The present study conducted an experiment and compared the performance of use of four different type of materials including wiry sponge, black volcanic rocks, coated metallic, and uncoated metallic wiry sponge. The experiment continued for 1 week and the performance was monitored on hourly basis. The results show that among the four materials used in the solar still, the coated metallic material had the highest productivity level; followed by the black volcanic rocks.

Keywords: Solar Still, Water, Material, Volcanic Rocks, Coated Metallic, Experiment.

\section{INTRODUCTION}

By the start of the $21^{\text {st }}$ century, the world population was about 6 billon which in the first two decades increase to above 7 billion. This increased population has resulted in increased demand for agriculture, domestic, and industrial products. All these human activities increasingly require fresh water which is becoming a scarcity. In many developing countries, the clean fresh drinking water is only available to fraction of the total population. Thus, there is increased demand for fresh water around the world. The lack of clean fresh water is also giving rise to several social 
problems such as food insecurity, epidemic diseases, and regional conflicts. Thus, there is increased need for establishing new methods of cleaning water to make it usable for human consumption. The sea is a big source of water but it is not usable by human due to the higher level of salt and other chemicals in it.

The desalination of water is becoming a trend in most countries. This is about purification of water using some technique such as electro dialysis, reverse osmosis, and other methods of distillation. However, there is need that while water purification technique is used, it must be based on the environmentally friendly practice. The environmentally friendly energy is started to use in some desalination plants in major countries around the world. Especially, the deserts and remote islands, where transportation cost is high, it is useful to install a solar energy source for water desalination. The cleaner energy-based plant has advantages including less carbon footprint, highly sustainable, and less operation cost. The disadvantage however is higher initial setup cost.

In this regard, a good work is done by Prasad and Tiwari (1996) who proposed a compound parabolic concentrator at the solar still basin for producing extra thermal energy for the purpose of cleaning the water. The system is also known as active solar system. The study by Prasad and Tiwari, concluded that as the glass cover inclination is increased, it also increase the rate of thermal energy. This implies that if glass cover is optimized, it can enable obtaining the most suitable results.

Building on the idea of solar still in desert, a study analyzed the simple solar still station performance compares to a similar one with flat plate collector (Boukar and Hannim, 2001). The experiment involved testing the performance in open with varying depths levels. For simple basis, the productivity during the summer season was minimum of $4.01 \mathrm{l} / \mathrm{m} 2 / \mathrm{d}$ which was much lower than the performance of the coupled one which showed results of minimum of $8.02 \mathrm{1} / \mathrm{m} 2 / \mathrm{d}$. Another study investigated the heat absorbing materials in four identical solar stills (Abdallah, Abu-Khader, \& Badran, 2009). Wiry sponge and black volcanic rocks, coated metallic, and uncoated metallic wiry sponge were used in first three stills; while, the fourth one used the reference still which does not contain any absorbing materials. Experiment results of the study showed that uncoated sponge outperformed the other material types in terms of water collection. Study by Badra (2011) was about thermal performance of a single solar still coupled with solar collector based on varying insulation thickness i.e. 3 and $6 \mathrm{~cm}$ along with temperature difference between water and cover, wind speed, transmissivity, absorptivity, and overall heat loss coefficient. The results of the study showed that if basin water temperature is increased by circulating hot water from the solar collector, it will improve the overall system efficiency. Another experimental study conducted by Singh (2011) who investigated the performance of single slope solar still based on different conditions such as sunshine or cloudy. The results of the study showed that when solar water heater and noctrunal is combined with solar still basin, the production can be improved by $120 \%$. Fuzzy sets were used on solar distillation system by Mamlook and Badran 6. The findings of the study were that different factors influence the solar 
still yield including the water depth, solar concentration, coupled collector, sprinkler, solar intensity, ambient temperature and wind speed.

A system consists of reflecting mirrors attached to slope of solar still based on a flat plate collector designed by Badra (2011). The comparison shows that this system improved the production. It was also observed in the study that increase in basin water depth bring reduction in the productivity and still productivity was proportional to the solar radiation intensity.

Study by Shanmugan, Rajamohan, and Mutharasu (2008) involved attaching booster mirror above the glass cover of the still basin of area $1 \mathrm{~m}^{2}$. The analysis showed that the booster mirror bring improvement in the overall production. In present study, experiment is designed to investigate that if addition of convace wick surface for evaporation and four sides of pyramid shaped still for condensation bring any improvement in the productivity. Absorbed solar ration were increased due to the jute wick and evaporation surface area is also increased. Because of capillary effects, evaporation area is increased because of concave shaped wick. The cost of the 1 liter of distillate water was about $\$ 0.071$ based on this solar still and the average capacity was $3.99 \mathrm{~m} 2 / \mathrm{d}$.

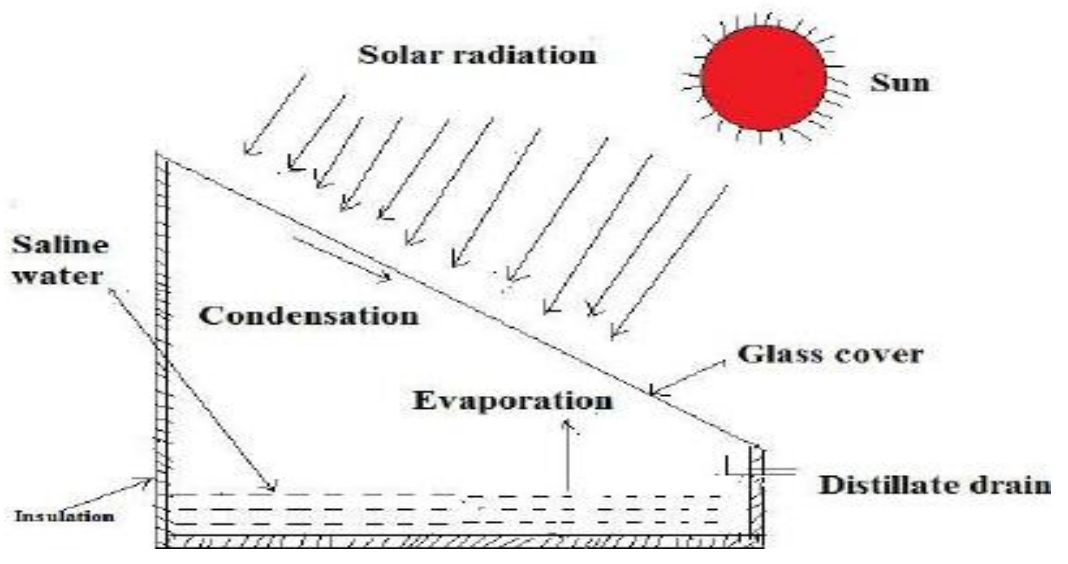

Figure 1: Underlying Mechanism of Solar Based Water Purification

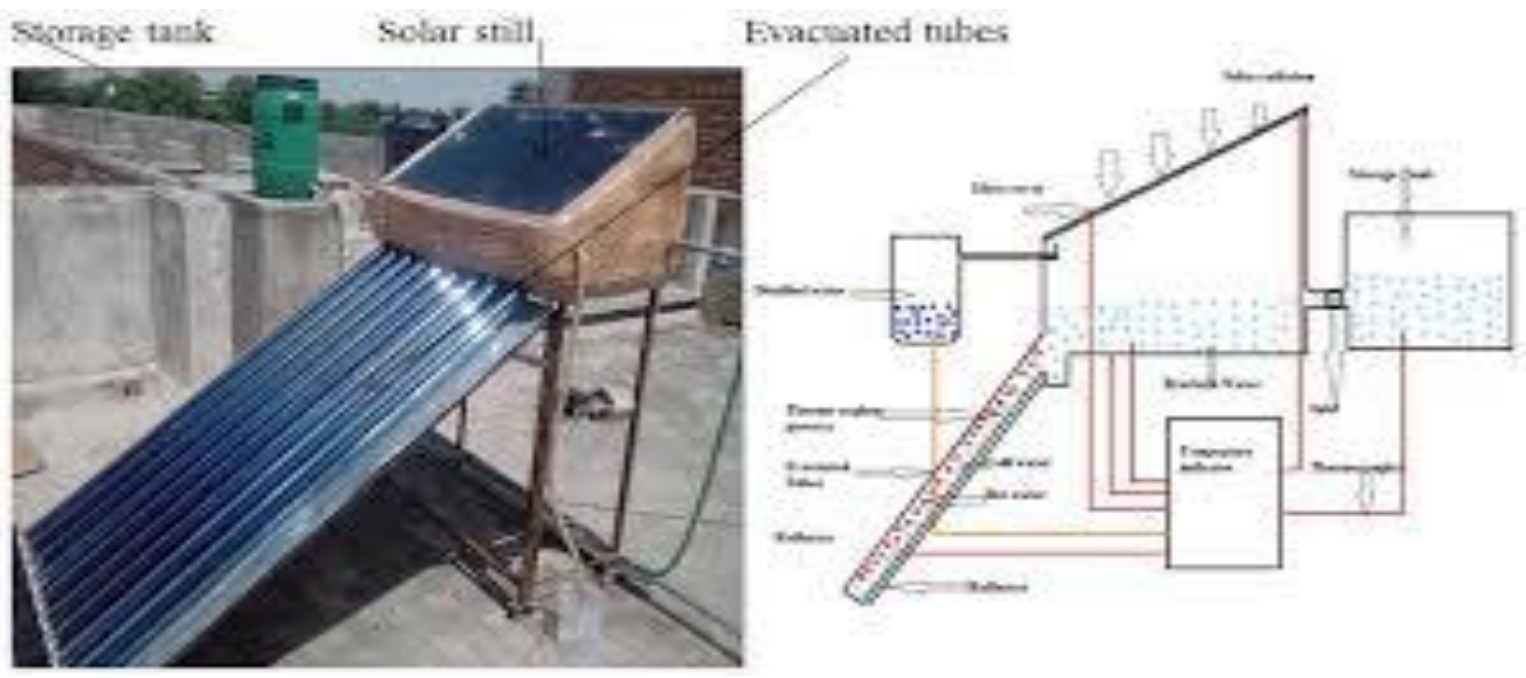

Figure 2: Solar Still 


\section{EXPERIMENT-MATERIAL AND METHODS}

The experiment involved coupling rows of parallel transparent evacuated glass tubes with single slope passive solar distillation unit where everyone consists of individual absorber tube having selective coating for warming the water before sending it to the solar still. The single slope solar still is integrated with evacuated glass tube. The evacuated glass tube is used for passing the water from the basin. The glass cover receives the solar heat and makes the water heated passing through the basin. At the same time, the outer glass is used for passing the solar radiation and accordingly, the fluid is flown through the absorber. the evacuated tubes refer to the modular tubes which can be added or removed based on the hot-water temperature requirement. These solar still has fiber reinforced plastic painted basin of area of $1 \mathrm{~m}^{2}$ which is used for supplying brackish water from EGT which preheat thee water by use of solar energy. A sheet of toughened glass is used for evaporating basin by permitting the sunrays directed to basin. The glass covering angle for tilting is about 40 degrees. There is a trough at the bottom which function as water collector. This glass is also keeping the heat for making continuous evaporation possible for the water in the basin. The water is feed in the still using the inlet pipe. For fixing the k-type thermocouples, there are holes drilled in the body of still. For water which is inside the basin, the evaporation is done using the evacuated glass tube collector. For preventing the leakage and heat losses, silicon rubber is used to function as a sealant. Polyurethane form is used for insulation of the solar still side and base walls. Dammar roll is fixed at the upper glass of the solar still. For controlling the brackish water inside the solar still, a constant head tank Is used. During this experiment, the water level is maintained at $08 \mathrm{~cm}$. the other technical specifications are that basin area is $1 \mathrm{~m}^{2}$, the inclination of glass is $40^{0}$, glass area is $1.024 \mathrm{~m}^{2}$, the glass depth is $6 \mathrm{~mm}$, the material of the paint is FRP and the number of glass is 1. Furthermore, the outer diameter of EGT is 50, the inner diameter is 40 and length is $1450 \mathrm{~mm}$. The inclination of EGT is $29^{\circ}$, and number of EGT is 16. The experimental setup is installed at open location under clear sky conditions with moderate temperature.

\section{RESULTS}

The results for the ambient temperature and the average output of water collection in $\mathrm{ml}$ for the entire experiment week is provided below.

Table 1: Experiment Result

\begin{tabular}{|c|c|c|c|c|c|c|c|c|c|c|c|c|}
\hline & \multicolumn{7}{|c|}{ Ambient Temperature (C) Day Wise } & \multicolumn{3}{c|}{ Average Output of Water Collection (mI) } \\
\cline { 2 - 13 } Time & & & & & & & & & $\begin{array}{c}\text { Wiry } \\
\text { Sponge }\end{array}$ & $\begin{array}{c}\text { Black } \\
\text { Volcanic } \\
\text { Rocks }\end{array}$ & $\begin{array}{c}\text { Coated } \\
\text { Metallic }\end{array}$ & $\begin{array}{c}\text { Mncoated } \\
\text { Wiry }\end{array}$ \\
\hline Hour 1 & 26.5 & 27.2 & 26.5 & 29.4 & 28.5 & 25.4 & 26.1 & 27.09 & 16 & 14 & 13 & 15 \\
\hline Hour 2 & 29.7 & 29.8 & 29.9 & 31.3 & 30.1 & 27.6 & 28.4 & 29.54 & 28 & 29 & 34 & 35 \\
\hline Hour 3 & 33.7 & 34.1 & 33.1 & 37.4 & 32.4 & 30.5 & 31.2 & 33.20 & 49 & 78 & 99 & 78 \\
\hline Hour 4 & 38.9 & 37.6 & 32.5 & 39.9 & 37.8 & 36.5 & 36.5 & 37.10 & 250 & 239 & 298 & 193 \\
\hline Hour 5 & 40.1 & 40.2 & 39.1 & 41.2 & 40.6 & 39.2 & 41.6 & 40.29 & 368 & 371 & 453 & 432 \\
\hline Hour 6 & 40.9 & 40.7 & 40.9 & 43.1 & 42.3 & 40.1 & 42.9 & 41.56 & 498 & 488 & 567 & 439 \\
\hline Hour 7 & 42.4 & 43.1 & 44.1 & 45.4 & 43.1 & 41.5 & 42.9 & 43.21 & 781 & 980 & 1121 & 788 \\
\hline
\end{tabular}




\begin{tabular}{|l|c|c|c|c|c|c|c|c|c|c|c|c|}
\hline Hour 8 & 43.7 & 43.9 & 42.1 & 44.9 & 43.4 & 42.6 & 43.9 & 43.50 & 899 & 1023 & 1178 & 877 \\
\hline Hour 9 & 37.2 & 38.9 & 39.2 & 40.1 & 44.5 & 36.5 & 37.4 & 39.11 & 965 & 1034 & 1234 & 890 \\
\hline Hour 10 & 39.1 & 37.7 & 36.4 & 39.5 & 39.1 & 38.4 & 38.6 & 38.40 & 879 & 1143 & 1278 & 913 \\
\hline Hour 11 & 33.5 & 35.2 & 34.4 & 37.7 & 38.7 & 32.1 & 32.1 & 34.81 & 678 & 878 & 981 & 832 \\
\hline Hour 12 & 30.2 & 31.9 & 32.1 & 31.3 & 33.4 & 29.8 & 30.8 & 31.36 & 345 & 432 & 566 & 430 \\
\hline Total & 435. & 440. & 430. & 461. & 453. & 420. & 432. & & & & \\
\hline
\end{tabular}

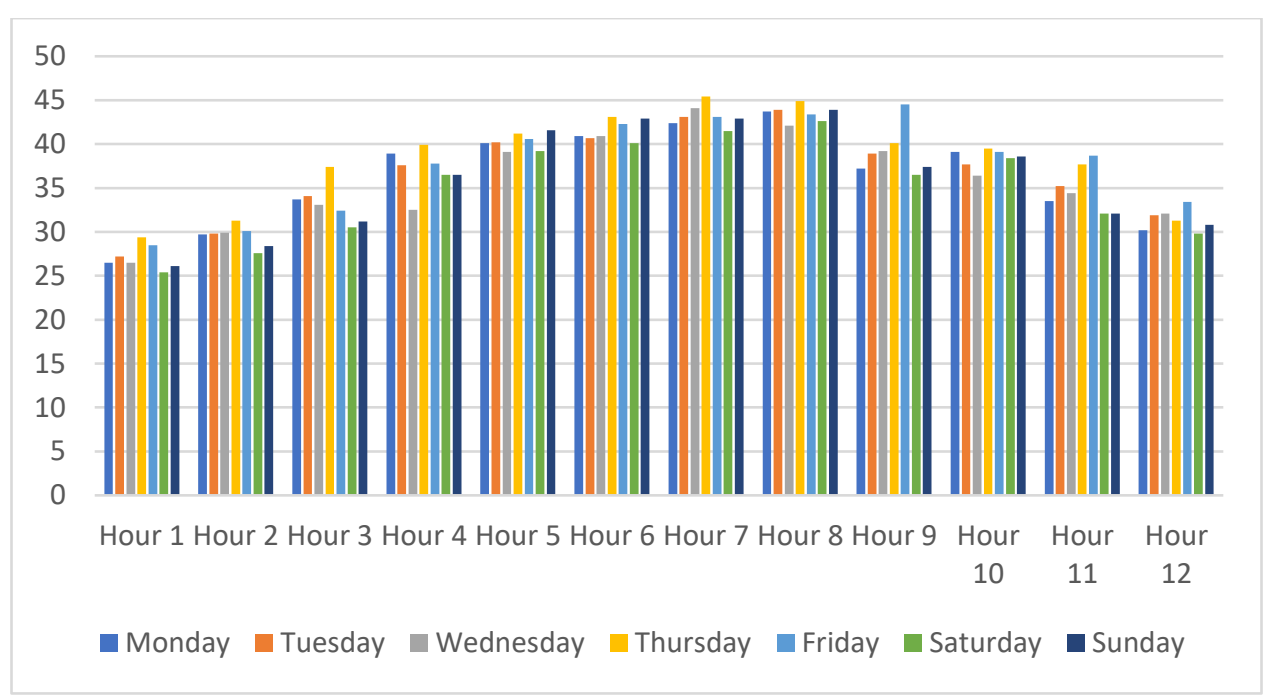

Figure 3: Temperature for 12 Hours -1 Week

The temperature for the entire week based on 12 hours is provided in the above chart.

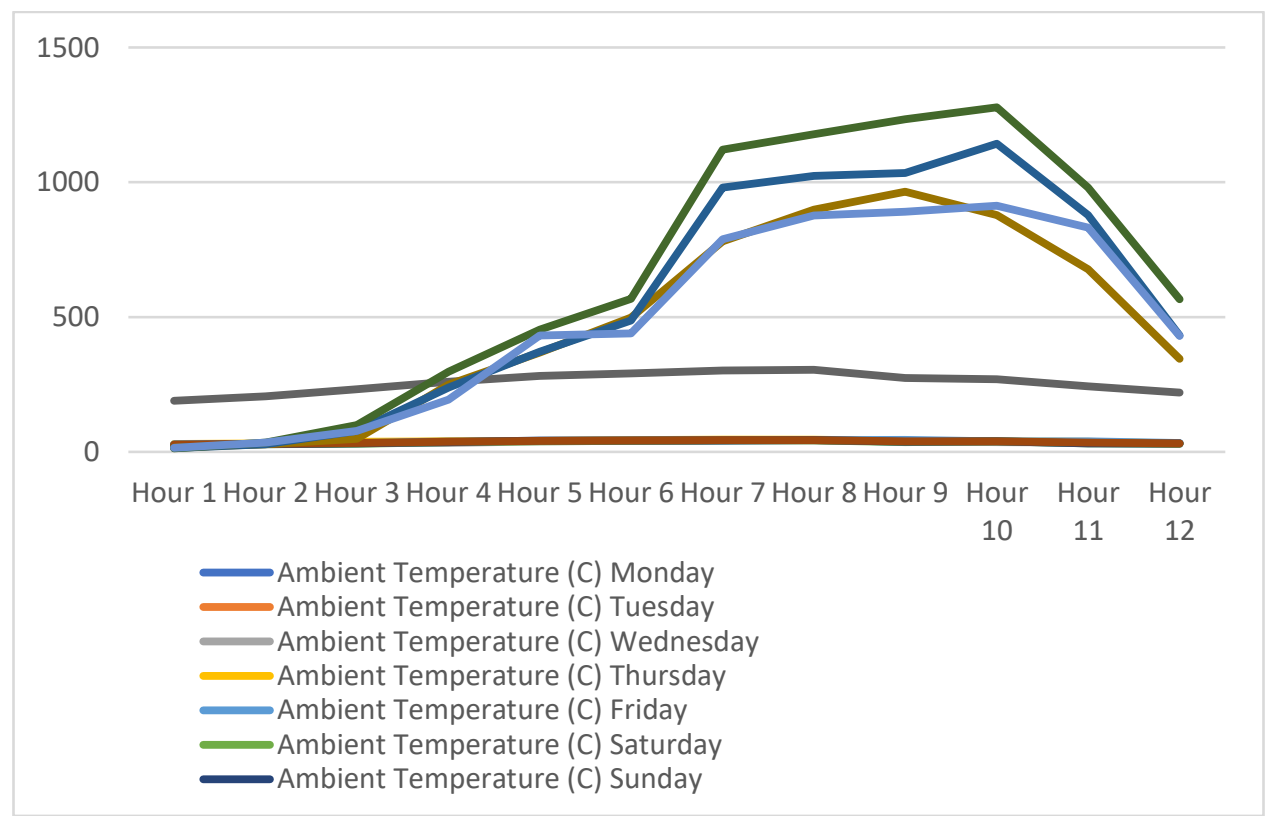

Figure 4: Ambient Temperature and Average Output for Week 
The ambient temperature for the entire week compared to the average output is provided in the above chart.

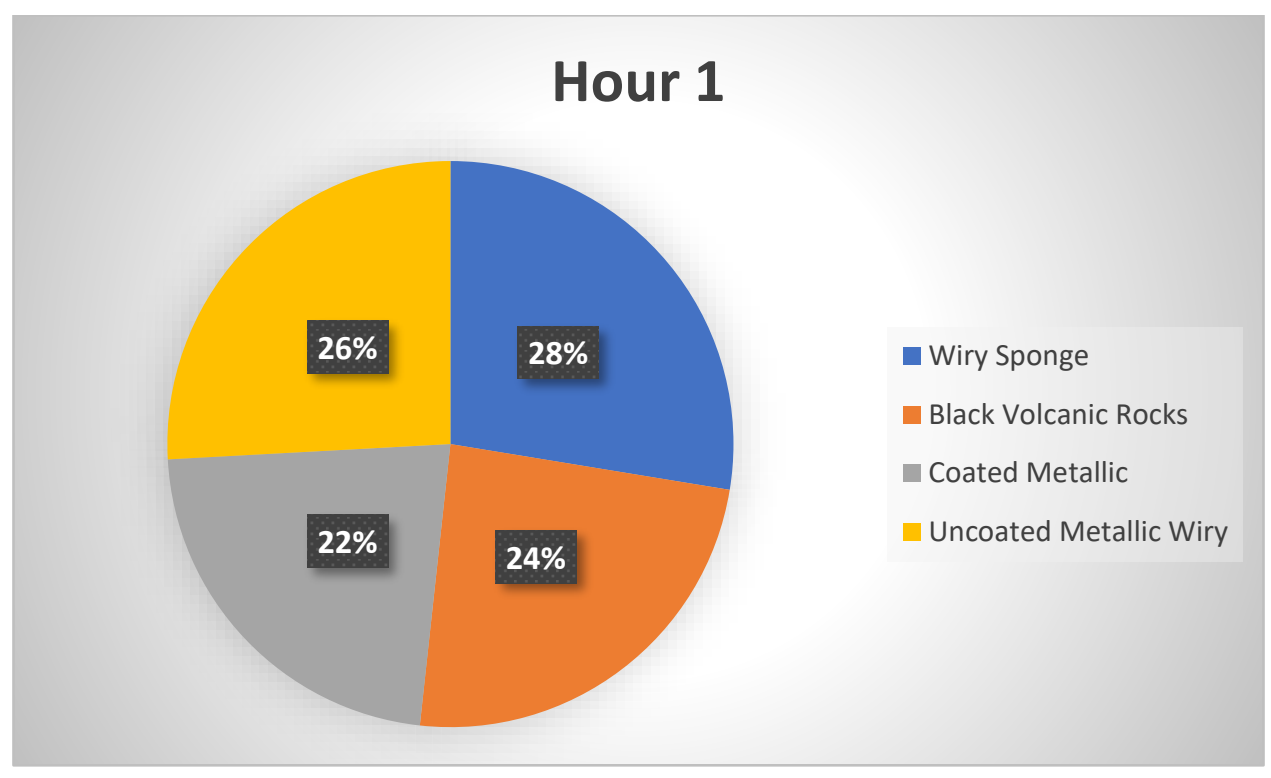

Figure 5: Hour 1 Average Output Comparison

The results show that at hour 1, the average temperature for the entire week was 27.09 and the average output of water collection in $\mathrm{ml}$ was 16 for wiry sponge, 14 for black volcanic rocks, 13 for coated metallic and 15 for uncoated metallic wiry.

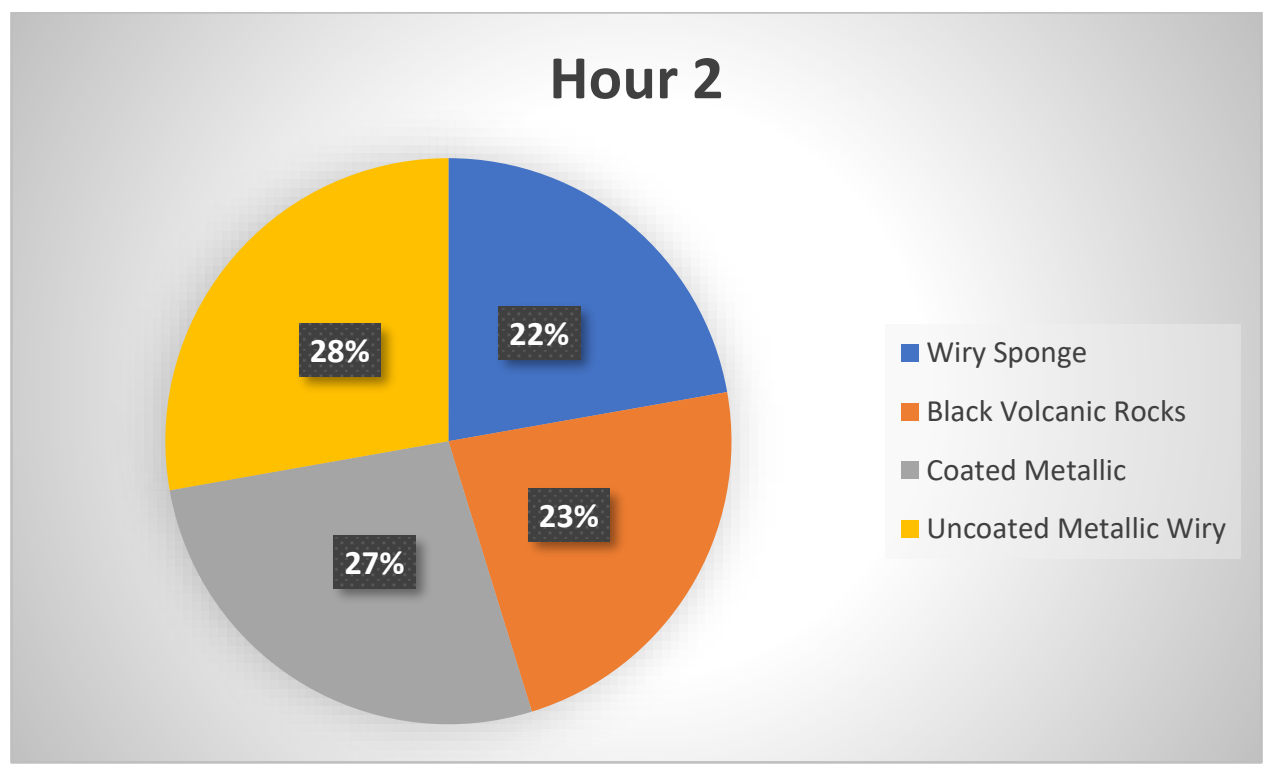

Figure 6: Hour 2 Average Output Comparison

At hour 2, the average temperature for the entire week was 29.54 and the average output of water collection in ml was 28 for wiry sponge, 29 for black volcanic rocks, 34 for coated metallic and 35 for uncoated metallic wiry. 


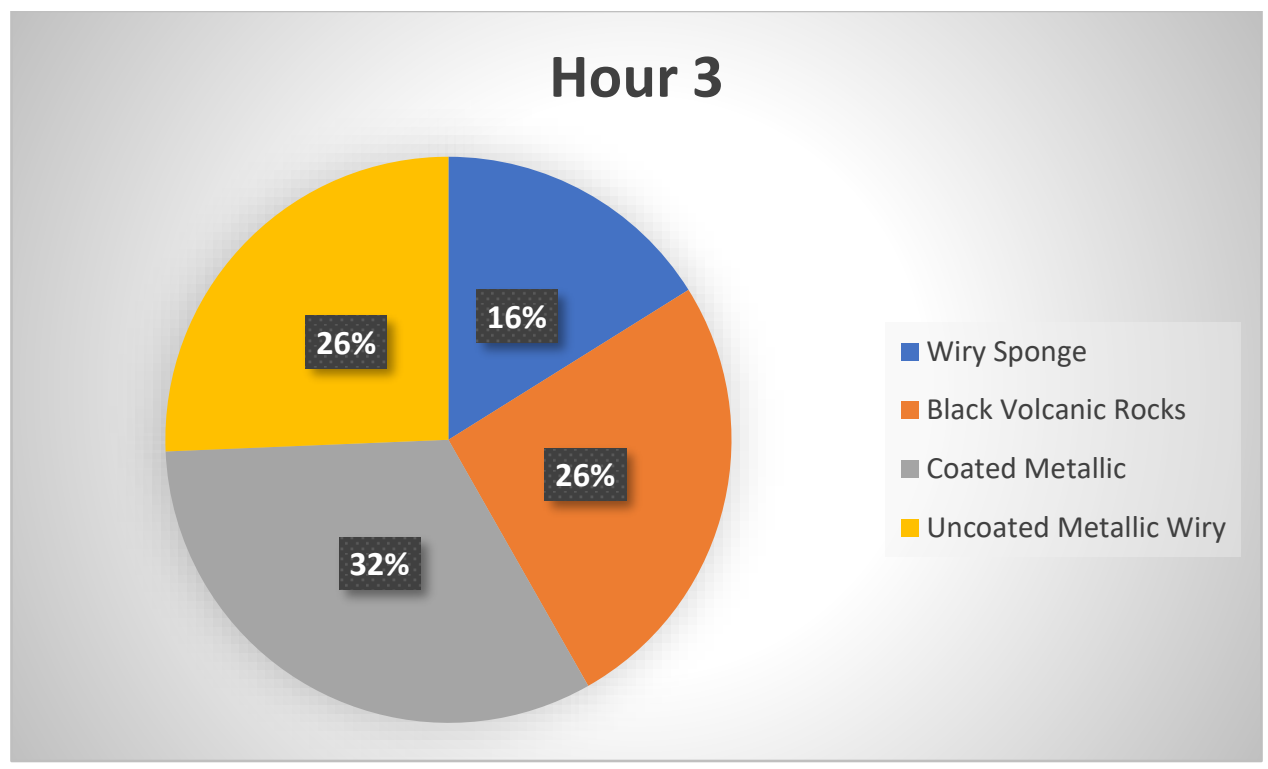

Figure 7: Hour 3 Average Output Comparison

At hour 3, the average temperature for the entire week was 33.2 and the average output of water collection in $\mathrm{ml}$ was 49 for wiry sponge, 78 for black volcanic rocks, 99 for coated metallic and 78 for uncoated metallic wiry.

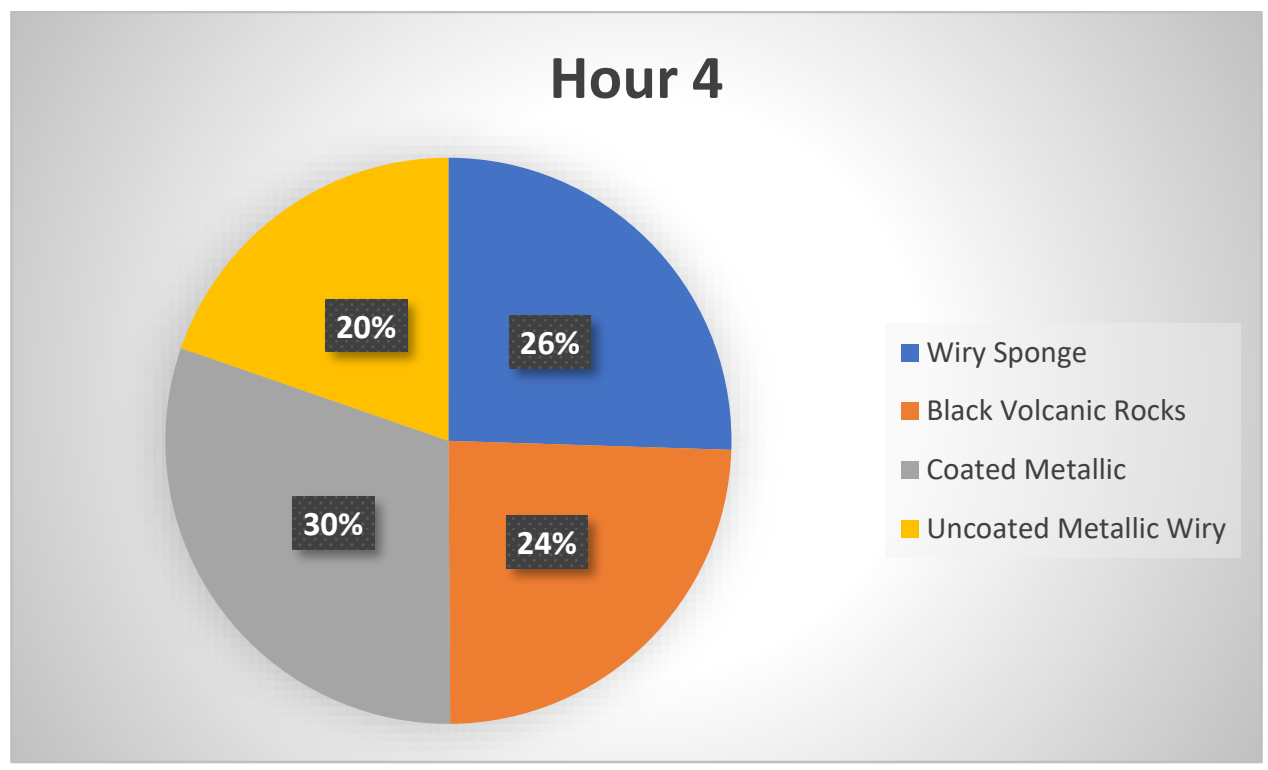

Figure 8: Hour 4 Average Output Comparison

At hour 4, the average temperature for the entire week was 37.1 and the average output of water collection in ml was 250 for wiry sponge, 239 for black volcanic rocks, 298 for coated metallic and 193 for uncoated metallic wiry. 


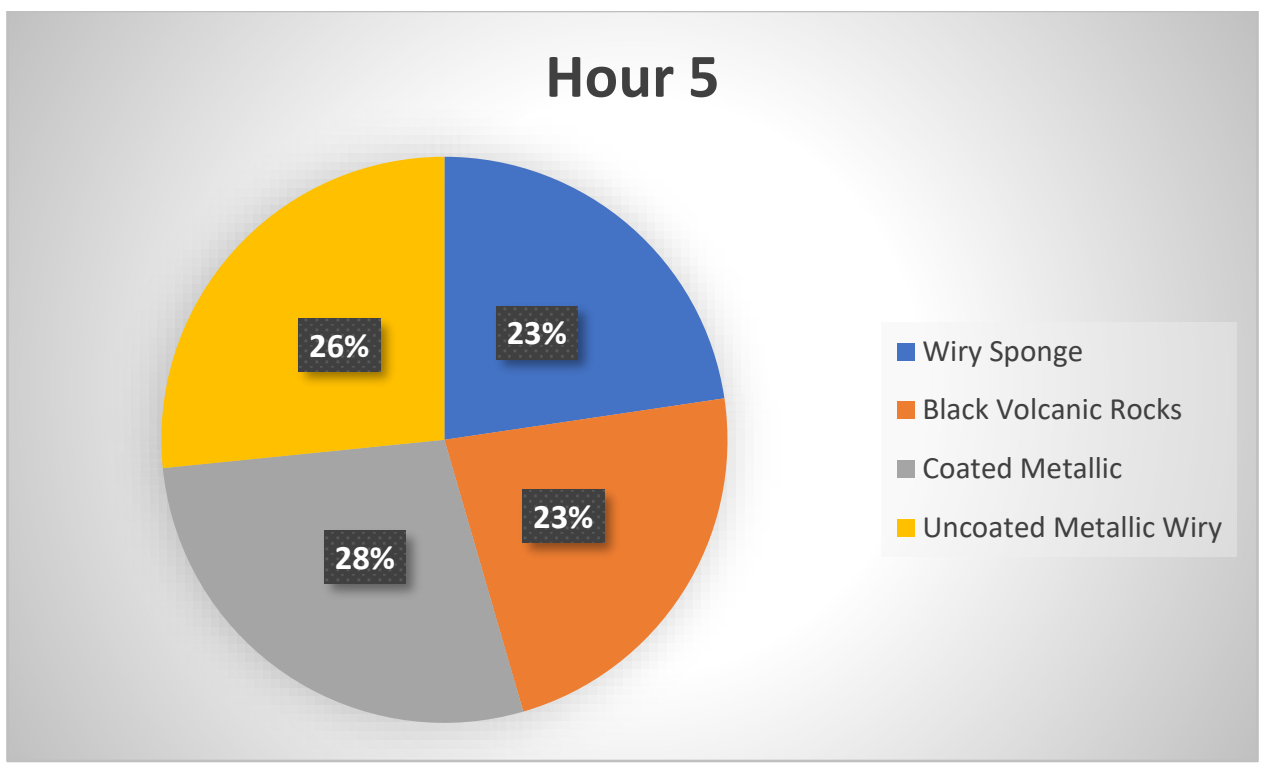

Figure 9: Hour 5 Average Output Comparison

At hour 5, the average temperature for the entire week was 40.29 and the average output of water collection in ml was 368 for wiry sponge, 371 for black volcanic rocks, 453 for coated metallic and 432 for uncoated metallic wiry.

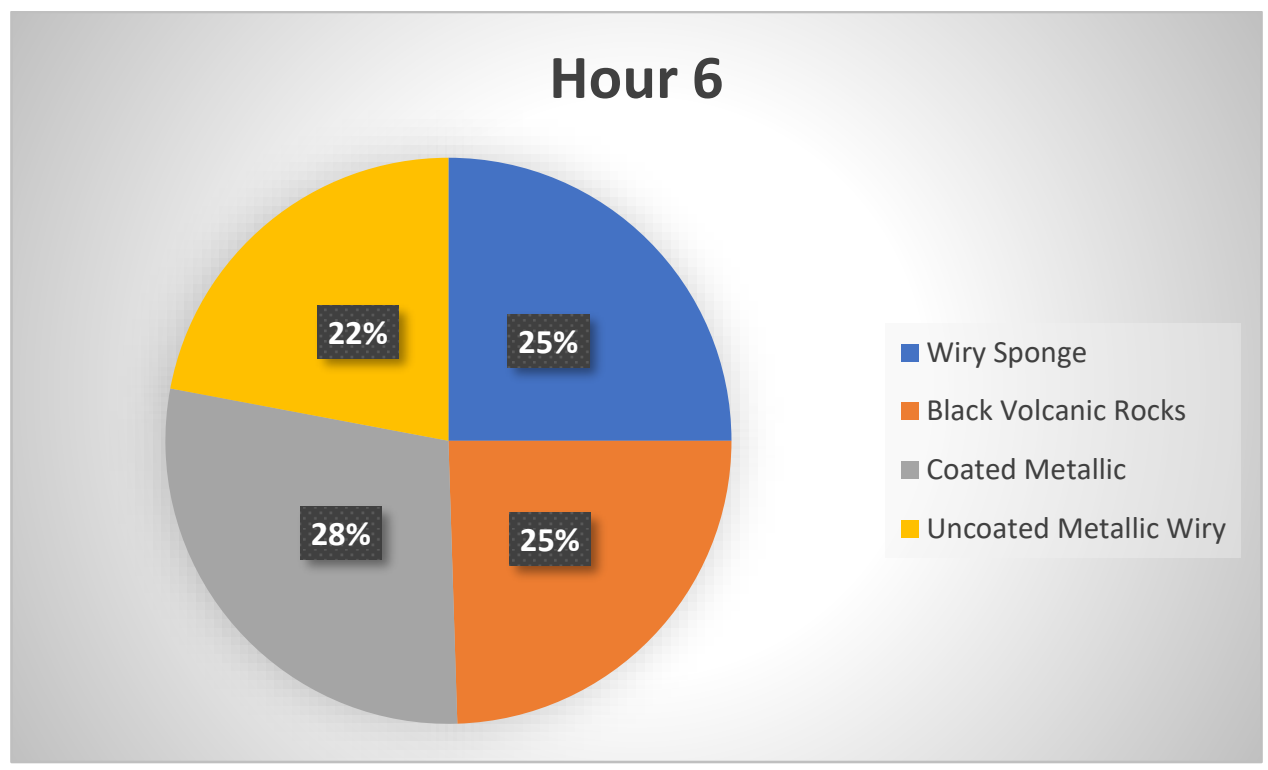

Figure 10: Hour 6 Average Output Comparison

At hour 6, the average temperature for the entire week was 41.56 and the average output of water collection in ml was 498 for wiry sponge, 488 for black volcanic rocks, 567 for coated metallic and 439 for uncoated metallic wiry. 


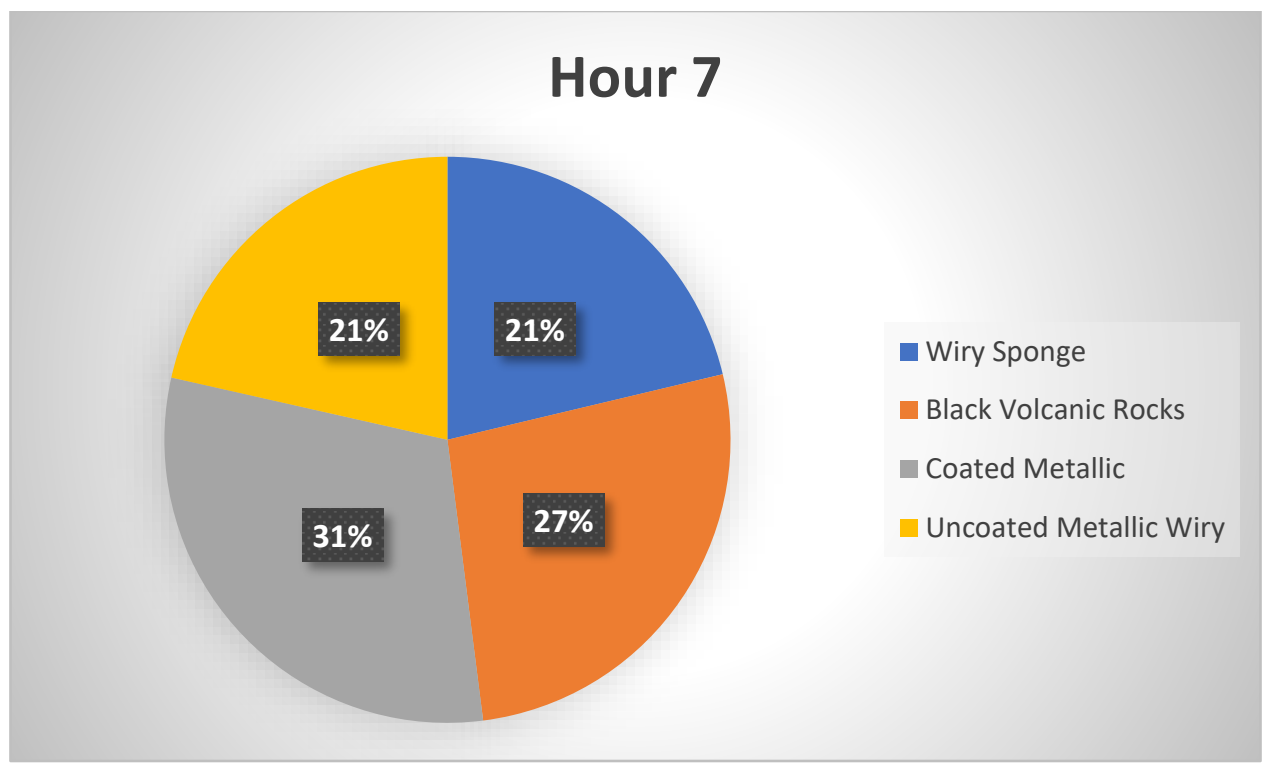

Figure 11: Hour 7 Average Output Comparison

At hour 7, the average temperature for the entire week was 43.21 and the average output of water collection in $\mathrm{ml}$ was 781 for wiry sponge, 980 for black volcanic rocks, 1121 for coated metallic and 788 for uncoated metallic wiry.

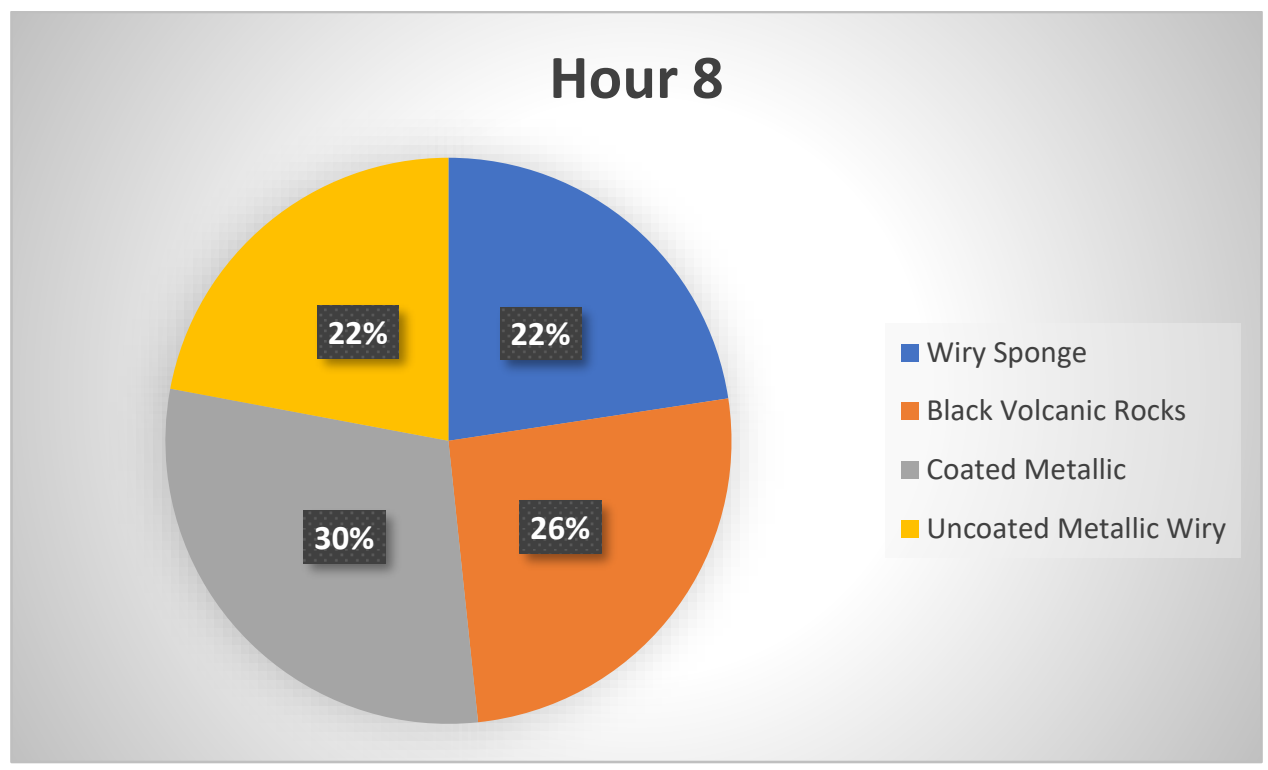

Figure 12: Hour 8 Average Output Comparison

At hour 8, the average temperature for the entire week was 43.5 and the average output of water collection in ml was 899 for wiry sponge, 1023 for black volcanic rocks, 1178 for coated metallic and 877 for uncoated metallic wiry. 


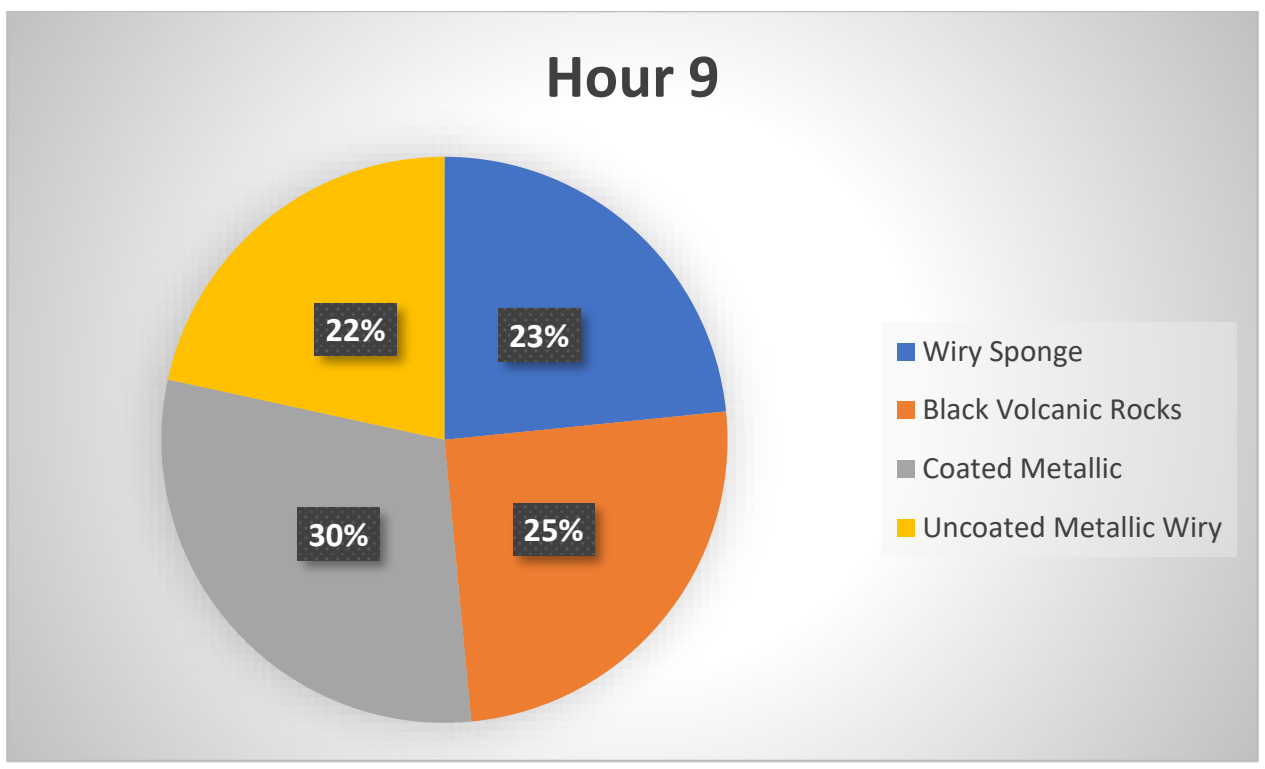

Figure 13: Hour 9 Average Output Comparison

At hour 9, the average temperature for the entire week was 39.11 and the average output of water collection in $\mathrm{ml}$ was 965 for wiry sponge, 1034 for black volcanic rocks, 1234 for coated metallic and 890 for uncoated metallic wiry.

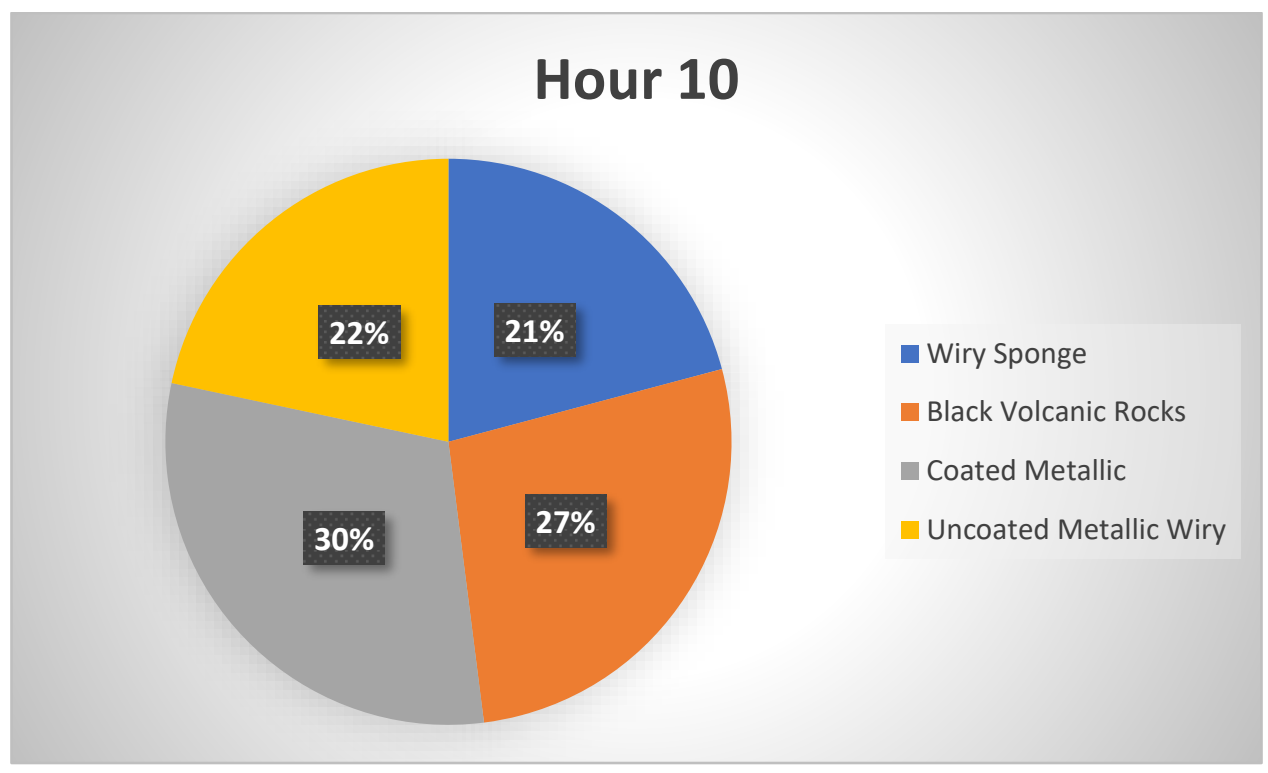

Figure 14: Hour 10 Average Output Comparison

At hour 10, the average temperature for the entire week was 38.4 and the average output of water collection in ml was 879 for wiry sponge, 1143 for black volcanic rocks, 1278 for coated metallic and 913 for uncoated metallic wiry. 


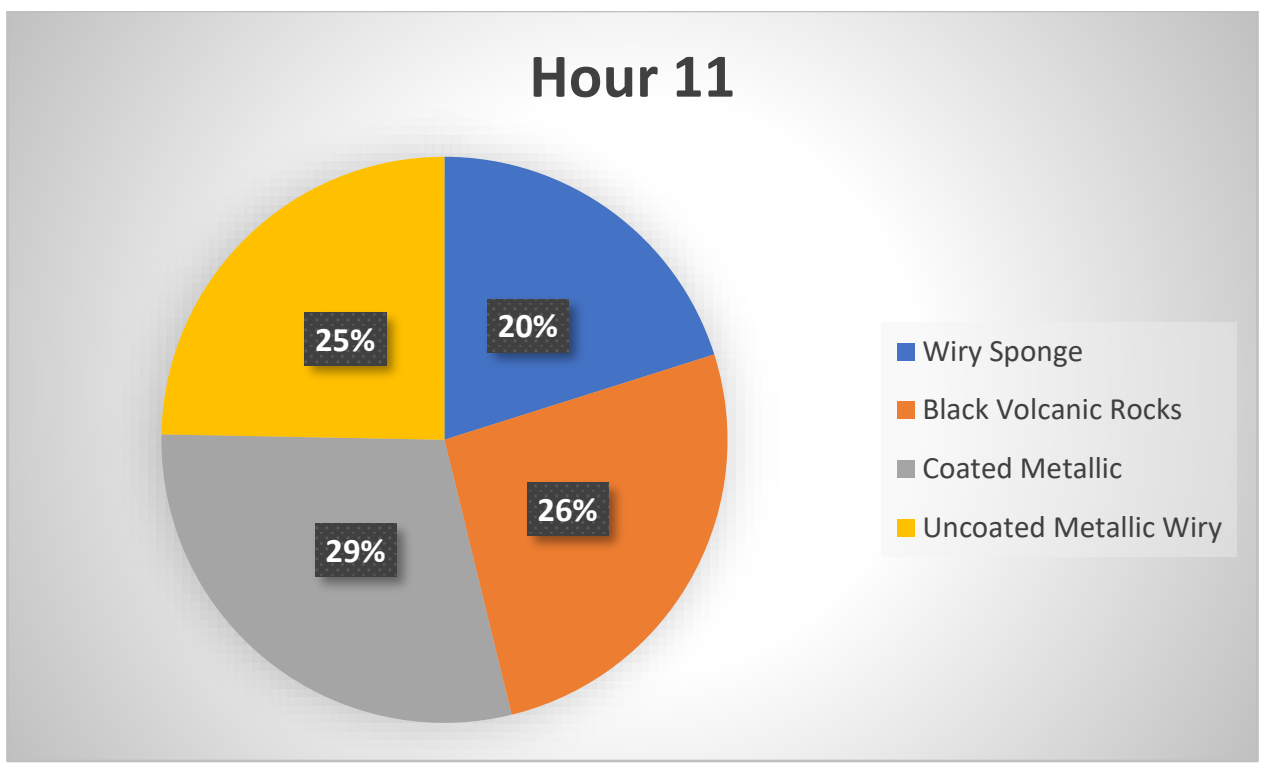

Figure 15: Hour 11 Average Output Comparison

At hour 11, the average temperature for the entire week was 34.81 and the average output of water collection in $\mathrm{ml}$ was 678 for wiry sponge, 878 for black volcanic rocks, 981 for coated metallic and 832 for uncoated metallic wiry.

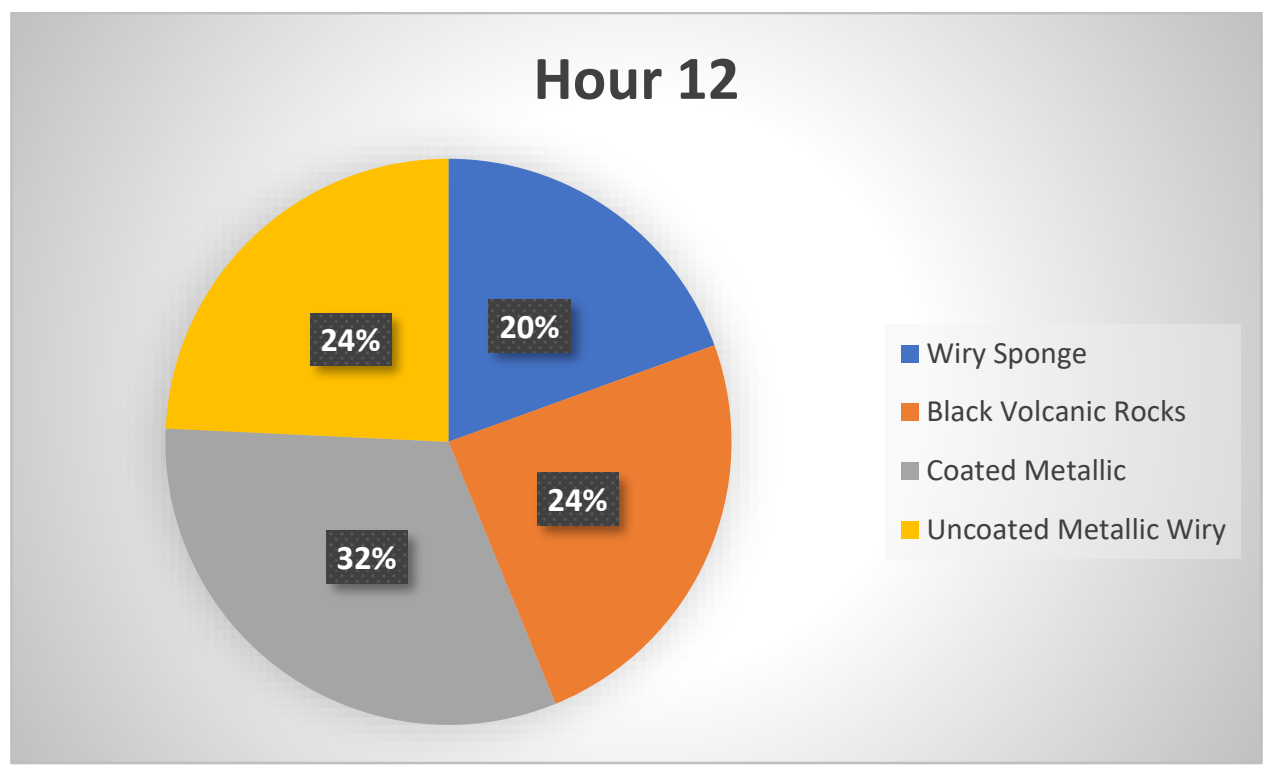

Figure 16: Hour 12 Average Output Comparison

At hour 12, the average temperature for the entire week was 31.36 and the average output of water collection in ml was 345 for wiry sponge, 432 for black volcanic rocks, 566 for coated metallic and 430 for uncoated metallic wiry. 


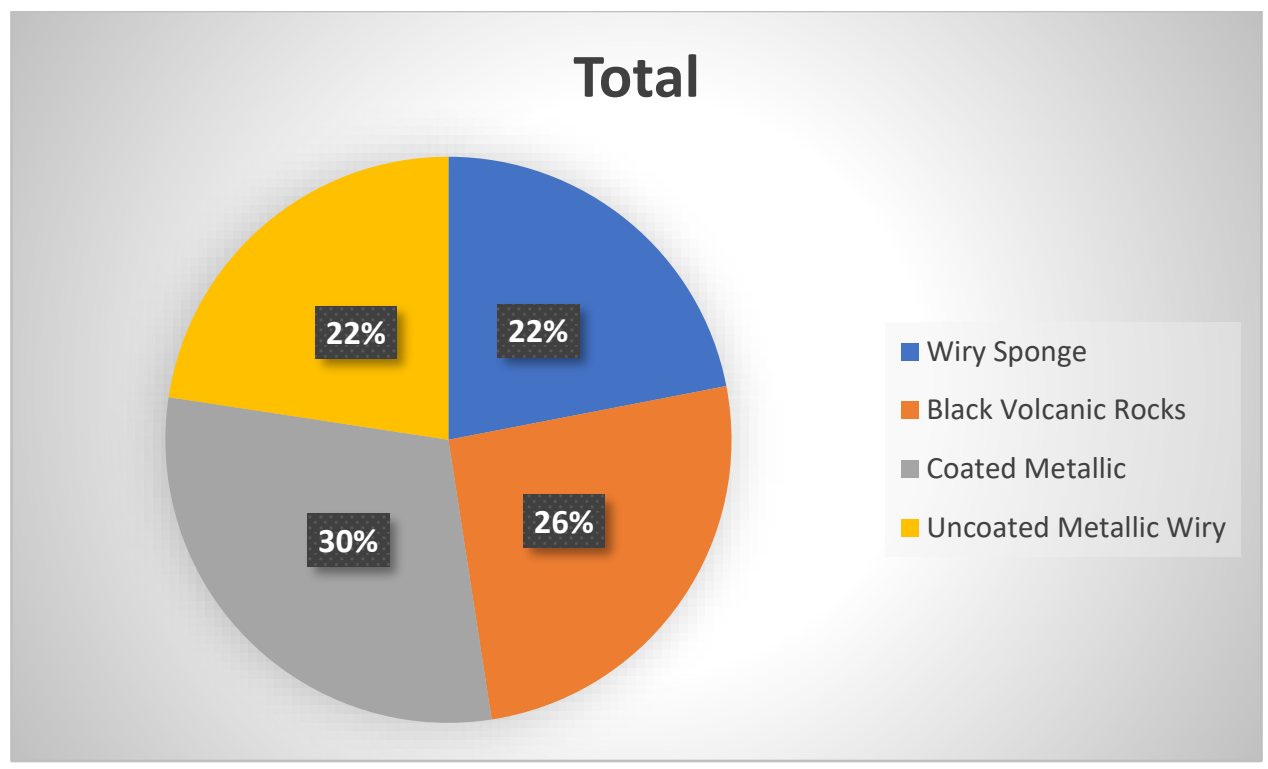

Figure 17: Average Output Comparison-Hourly Basis for Entire Experiment

In total, for the entire week, the average output of water collection was $22 \%$ for wiry sponge, $26 \%$ for black volcanic rocks, $30 \%$ for coated metallic and $22 \%$ for uncoated metallic wiry. Thus, our results show that the coated metallic is the most useful material for the water purification in terms of solar based system compared to the other metallic. The second-best option based on our experiment is the black volcanic rocks; while, the wiry sponge and the uncoated metallic wiry had equal results and stood at $22 \%$.

\section{CONCLUSION}

In this study, we focused on desalination of water using the solar still technique which is considered as an environmentally friendly technique based on its carbon footprint. The system is also considered as more economical. In this study, we investigated that how four types of materials including wiry sponge, black volcanic rocks, coated metallic, and uncoated metallic wiry sponge can be used in four stills using the experimental approach. The experiment continued for 1 week and for 12 hours, the monitoring of the collected water output was performed. The results show that among the four materials, the coated metallic material outperformed the other materials in terms of the average output of water collection for the experiment week. The second-best material based on our study was the black volcanic rocks; while, the wiry sponge and uncoated metallic wiry had lower performance in terms of average output of water collected.

\section{References}

Abdallah, S., Abu-Khader, M. M., \& Badran, O. (2009). Effect of various absorbing materials on the thermal performance of solar stills. Desalination, 242, 128-137

Badra, O. (2011). Theoretical analysis of solar distillation using active solar still. International Journal of Thermal and Environmental Engineering, 3(2), 113-120. 
Boukar, M., \& Harmim A. (2001). Effect of climatic conditions on the performance of a simple basin solar still: a comparative study. Desalination, 137, 15-22.

Mamlook, R., \& Badran, O. (2007). Fuzzy sets implementation for the evaluation of factors affecting solar still production. Desalination, 203, 394-402.

Prasad, B., \& Tiwarl, G.N. (1996). Effect of glass cover inclination and solar distillation system parametric studies of concentrator-assisted. International journal of energy research, 20, 495-505.

Shanmugan,S., Rajamohan, P., \& Mutharasu, D. (2008). Performance study on an acrylic mirror boosted solar distillation. Desalination, 230, 281-287.

Singh, B.P. (2011). Performance Evaluation of a Integrated Single Slope Solar Still With Solar Water Heater. MIT International Journal of Mechanical Engineering, 1(1), 68-71. 